\title{
FOXC1 wt Allele
}

National Cancer Institute

\section{Source}

National Cancer Institute. FOXC1 wt Allele. NCI Thesaurus. Code C131543.

Human FOXC1 wild-type allele is located in the vicinity of $6 \mathrm{p} 25$ and is approximately $4 \mathrm{~kb}$ in length. This allele, which encodes forkhead box protein C1, is involved in both embryogenesis and eye development. Mutations in this gene are associated with Peters anomaly, primary congenital glaucoma, autosomal dominant iridogoniodysgenesis type 1, and Axenfeld Rieger syndrome 3. 